\title{
A SENTENCE NEED NOT BEGIN WITH A CAPITAL LETTER
}

\author{
Jakob Patekar* \\ Rochester Institute of Technology Croatia
}

This paper examines the challenge of starting a sentence with a proper noun or an abbreviation that is written with an initial lowercase letter (e.g. iPhone, danah boyd, pH). Traditionally, placing such words at the beginning of a sentence would be avoided, but this limits one's syntax and style. Hence, the aim of this paper is to explore the rules and practices of writing certain proper nouns and abbreviations with a lowercase letter and starting a sentence with such words in Croatian and English. Therefore, we reviewed the rules and guidelines in orthography handbooks and style guides, analyzed the corpora to examine the use of the initial lowercase letter, and surveyed a group of 60 bilingual college students to gain an insight into what they find acceptable regarding the matter. The results show that a sentence can indeed begin with a lowercase letter and that the acceptability of this phenomenon depends on several factors.

Keywords: capital letter, uppercase, lowercase, capitalization, orthography, proper nouns, brand names.

\section{INTRODUCTION}

One of the rules that children learning to write cursive acquire first - and quite easily - is that a sentence should always begin with a capital letter'; this is the case in both Croatian and English. The rule seems so simple and logical that rarely anyone struggles with it. While as adults we may not be sure what to capitalize when it comes to other words in a sentence, we most definitely know that the sentence should start with a capital letter. In fact, Truss (2003: 23) notes that the rule is "so ingrained that word-processing software will not allow you to type a full stop and then a lower case letter". This is not surprising considering that, unlike many other rules governing punctuation and capitalization, the rule above has gone unquestioned for hundreds of years ${ }^{2}$.

\footnotetext{
jakob.patekar@outlook.com

1 The capital letters are called so because "they 'head' the beginning of a sentence, or a word or expression of special significance. (Capital embodies the Latin word caput, 'head.')" (Peters, 2004: 90). They are also known as uppercase letters because printers stored them "in the upper section of the tray containing the units of typeface, while the ordinary letters ('lower case' letters) were kept in the lower and larger section of the tray" (Peters, 2004: 90).

${ }^{2}$ According to Truss (2003: 22), in English, "[ $[\mathrm{t}]$ he initial letter of a sentence was first capitalised in the $13^{\text {th }}$ century, but the rule was not consistently applied until the $16^{\text {th" }}$.
} 
However, what happens when at the beginning of a sentence we choose to put a proper noun, the first letter of which is written in lowercase, whether it is a company (eBay), a product (iPhone), a person's name (danah boyd), or an abbreviation such as $p H$ ? Traditionally, the advice would be to avoid placing such words at the beginning of a sentence, but this also means limiting one's syntax and style. The challenge has, in fact, been around for quite a while. Crystal (2005) notes that it was in the 1980s that organizations began writing their names in lowercase letters because they sensed that they "suggest freshness, modernity, and informality". Trendsetters, such as $k d l^{l a n g} g^{3}$, claims Crystal (2005: 392), were quick to follow suit, "and it was not long before the usage began to influence book and film titles".

It seems that with the rise of internet communication, the capital letter continued to lose its prestigious status ${ }^{4}$. As Crystal (2004: 170) describes, "[b]ecause most of the Internet is not case-sensitive, a random use of capitals has developed, or the use of no capitals at all. There is a strong tendency to use lower-case everywhere". Indeed, Crystal (2004: 173) calls this "the lower-case default mentality". A couple of years later, Crystal (2006b: 93) notes that "the new names cause difficulty, in that longstanding orthographic conventions are contravened: for example, sentences can begin with small letters, as in eBay is interested or iMac is the answer". Several years later, Crystal (2012: 307) reiterates that we "have never seen anything before quite like the use of a lower-case initial for a brand-name, as in iPod, iPhone, iSense and eBay, or airline companies such as easyJet and jetBlue" and points out that it is not clear how to deal with these names if we want to start a sentence with them ${ }^{5}$.

Crystal (2012) does recognize that another age-old rule regarding the beginning of a sentence is being broken in the $21^{\text {st }}$ century. The rule in question refers to starting a sentence with a number - the number should be spelled out instead of using a numeral. Crystal (2012) offers a logical explanation by stating that originally, "printers felt that, if numerals were allowed in an initial position, it would be difficult to see where one sentence ended and the next began" but acknowledges that "[ $t]$ he rule nonetheless has often been broken, and these days we often see numeral-initial sentences, especially on the Internet" (Crystal, 2012: 364-365). The explanation given above has an important implication for understanding the point of capital letters - they seem to serve the purpose of making the text more readable by helping the reader discern the beginning of a sentence. Indeed, Crystal (2015:

\footnotetext{
${ }^{3}$ Canadian singer and songwriter.

${ }^{4}$ However, we should not forget that in English, the loss of capital letters had happened once before nouns in English were capitalized in the $17^{\text {th }}$ century but this trend waned and disappeared toward the end of the $18^{\text {th }}$ century (Crystal, 2006a).

${ }^{5}$ Crystal (2012: 307-308) notes that this phenomenon is referred to as "bicaps (bicapitalisation), intercaps, incaps, medial caps and midcaps, as well as more picturesque names such as CamelCase (the capitals form the humps) and BumpyCase".
} 
501) highlights that "[i]nitial capitals complement periods in identifying sentences".

Other authors are more vociferous when it comes to the initial capital letter. Baranick (2014), for example, says that she is irked by corporations because "they are responsible for the capitalization crisis that is currently plaguing our nation" and identifies Apple as the main culprit as their "iPods, iPhones, and iPads are so dang cool that to be just like them much of the nation has stopped capitalizing the word I" (Baranick, 2014: 154).

While Crystal and other authors, some of whom we refer to later, focus on company and brand names and a few individuals, the fact is that there are abbreviations from several fields that start with a lowercase letter, such $\mathrm{pH}$, rDNA, mRNA, hPSC, mESC, mA, etc. Thus, the issue of starting the sentence with a lowercase letter encompasses proper nouns (personal, company, and product names) and abbreviations.

The aim of this paper is to examine the rules and practices of writing certain proper nouns and abbreviations with a lowercase letter and starting a sentence with such words. Therefore, in Literature Review we first reviewed the rules and guidelines in orthography handbooks and style guides, then in the first study we analyzed the corpora in both languages to examine the use of the initial lowercase letter at the beginning of a sentence, and in the second study we surveyed a group of 60 bilingual college students to gain an insight into what they find acceptable regarding the matter. The two studies are presented separately, but the implications of both are discussed in the section General Discussion, which is followed by a conclusion.

\section{LITERATURE REVIEW}

In this part we explore major orthography and style handbooks in both Croatian and English to gain an insight into the rules governing the initial capital letter in proper nouns, abbreviations, and at the beginning of a sentence.

Four most prominent Croatian orthography handbooks (Anić \& Silić, 2001; Babić \& Moguš, 2011; Badurina, Marković \& Mićanović, 2008; Jozić, 2013) are unanimous in stating that the first word in a sentence is written with an initial capital letter. However, Badurina, Marković and Mićanović (2008: 119) leave some room for freedom of choice when it comes to certain text types, such as advertisements, claiming that "capital and lowercase initial letters are used quite freely" (our translation) as such use is not governed by orthographic but graphological rules. Furthermore, Jozić (2013) makes an exception to the initial capital letter rule and states that if a proper noun begins with the letter $e$ or $e$-, the letter $e$ remains lowercase at the beginning of a sentence. The following examples are provided: 
"e-Hrvatsku pratim redovito." (e-Hrvatska I follow regularly) and

"eMetković čitam ponedjeljkom." (eMetković I read on Mondays) (Jozić, 2013: 138)

When it comes to proper nouns, Jozić (2013) allows for lowercase letters for registered trademarks and provides the examples iPad and iPhone (but these are not mentioned in the context of starting a sentence). Thus, we see that a precedent has been set by Jozić (2013) when an exception has been made for a certain type of proper nouns to be written with a lowercase letter and that a sentence can be started with a lowercase letter if it begins with an $e$-word.

As for the rules in the English language, it needs to be noted that the English language does not have orthography handbooks in the sense that Croatian does (Patekar, 2016). Punctuation, capitalization, and spelling rules are thus found in style and usage manuals and guides (e.g. Oxford Style Manual, The Cambridge Guide to English Usage) and in-house style guides of certain newspapers (e.g. The Economist Style Guide, The New York Times Manual of Style and Usage) and associations (e.g. Publication Manual of the American Psychological Associations, MLA Handbook).

We first turn to one of the most comprehensive handbooks, the Oxford Style Manual [OSM] (Ritter, 2003). As stated in OSM, the role of capital letters is to "punctuate sentences and to distinguish proper nouns from other words" (Ritter, 2003: 71). However, there are exceptions as OSM advocates that writers " $[\mathrm{u}] \mathrm{se}$ the form of name individuals are most commonly known by, or know to prefer" (Ritter, 2003: 83) and provides the example, among others, of $k$. d. lang. It is not clear what happens to lowercase initial proper names at the beginning of a sentence, but OSM does state that last name prefixes such as van, van den, van der in Dutch, von, von der, vom in German and de in French are capitalized if found at the beginning of a sentence. As for lowercase abbreviations, they "usually obey the rules that normally govern punctuation and styling in running text, which means that lower-case abbreviations cannot begin a sentence in their abbreviated form" (Ritter, 2003: 64).

The Chicago Manual of Style [CMOS] (2017), another quite popular reference book, is explicit about writing brand names and trademarks with lowercase initial letters followed by a capital letter at the beginning of a sentence by stating that they "need not be capitalized" (CMOS, 2017: 538) because the capital letter within the word shows that this is a proper noun. It is interesting to note here the rationale for allowing intercaps but not all lowercase names to retain their spelling - the capital letter serves the purpose of identifying proper nouns. The authors provide the following example: "iTunes is both an app and a media service." For names in all lowercase letters, CMOS requires capitalization in order to signal that the word is a proper noun and thus redacts "mini" to "Mini" in the following example: 
"The Mac Mini is a good solution for cluttered workspaces." As for personal names, CMOS (2017: 462) states that "[u]nconventional spellings strongly preferred by the bearer of the name or pen name (e.g., bell hooks ${ }^{6}$ ) should usually be respected in appropriate contexts", but warns that "[m]ost editors will draw the line at beginning a sentence with a lowercased name and choose either to rewrite or to capitalize the first letter for the occasion". The authors of CMOS make an interesting observation regarding the oft-used example of e. e. cummings, an American poet and playwright, saying that “E. E. Cummings can be safely capitalized; it was one of his publishers, not he himself, who lowercased his name" (CMOS, 2017: 462).

The latest, seventh, edition of the widely used APA Publication Manual (American Psychological Association, 2020: 165), advocates that "a personal name that begins with a lowercase letter when the name begins a sentence" should not be capitalized or, alternatively, the sentence should be reworded. The following example is provided: "...after the test. van de Vijver et al. (2019) concluded" (APA, 2020: 165). The rule thus applies to last name prefixes as well. As for "a proper noun (other than a personal name) that begins with a lowercase letter (e.g., iPad, eBay) or a lowercase statistical term (e.g., $t$ test, p value)" (APA, 2020: 165) the Manual states that the sentence should be reworded "to avoid beginning with a lowercase letter" (APA, 2020: 174). The Manual explicitly states that lowercase abbreviations should not be placed at the beginning of a sentence. Here it is important to observe the distinction being made between personal names and other proper nouns, which seems to be an attempt to establish some sort of hierarchy of lowercase words that can find their place at the beginning of a sentence.

Trask (2001), a well-known authority on the English language usage, is strongly against the lowercase initial trend, stating that "it is out of order to refrain from using necessary capitals in order to draw attention to yourself. The British Film Institute, which used to be known as the BFI, now formally styles itself the bfi. This is pretentious, irritating and entirely unnecessary" (Trask, 2001: 59). Interestingly, albeit in a different, earlier publication, Trask (1997) shows lenience towards personal names, saying that "a few people eccentrically prefer to write their names with no capital letters at all, such as the poet $e$. e. cummings and the singer $k$. $d$. lang. These strange usages should be respected" (Trask, 1997: 78). Walsh (2004), on the other hand, would capitalize all personal names regardless of what the name-bearers prefer, stating that "[t]he seemingly simple issue of capitalizing proper nouns has gotten muddied somewhat by e.e. cummings and k.d. lang and 'thirtysomething' ${ }^{\prime 7}$ and cutesy all-lowercase company names. The short

\footnotetext{
6 An American scholar.

7 A popular American TV series from the 1980s.
} 
answer is that the usual rules apply. You're a writer, not a logo replicator, and the capitalization of proper nouns is one of the most basic principles of English orthography" (Walsh, 2004: 25). However, he does allow for an exception in view of proper nouns that do contain a capital letter "within a letter or two: eBay, iMac" (Walsh, 2004: 25). Still, Walsh (2004) urges the readers to never begin a sentence with a lowercase letter, explaining that the initial capital letter rule "trumps all: IMacs are for sale on eBay" (Walsh, 2004: 26).

The Copyeditor's Handbook (Einsohn, 2006) recognizes that policies on the treatment of initial lowercase names vary and mentions in fact Walsh's "spirited defense of using standard capitalization despite the individual's preference" (Einsohn, 2006: 152) in contrast to other publishers who do "respect the lowercasers' preference" (Einsohn, 2006: 153). The Handbook suggests trying to avoid placing the lowercased name at the beginning of a sentence, offering the following examples:

"Awkward: bell hooks is the pen name of Gloria Watkins.

Preferable: Gloria Watkins uses the pen name bell hooks." (Einsohn, 2006: 153)

The Handbook does note that in the case the name appears frequently this may become a cumbersome strategy, in which case the copyeditor should check with the author and the editorial coordinator if the initial letter should be capitalized at the beginning of a sentence.

Finally, Straus, Kaufman and Stern (2014: 52) in their Blue Book of Grammar and Punctuation mention the issue only in relation to trademarks and thus claim that if "a trademark starts with a lowercase word or letter (e.g., eBay, iPhone), many authorities advise capitalizing it to begin a sentence". They do not, however, say who the authorities are, but they do provide an example: "EBay opened strong in trading today" (Straus, Kaufman \& Stern, 2014: 52).

Other handbooks that we examined (Burchfield, 1998; Lovinger, 2002; Manser \& Curtis, 2002; Merriam-Webster's Guide to Punctuation and Style, 2001; Seely, 2009; Woods, 2006) do not explicitly address the issue of a proper noun written with an initial lowercase letter or starting a sentence with such a word. They are unanimous in stating that proper nouns are written with an initial capital letter and that the beginning of a sentence is always capitalized.

At this point it would not be amiss to consider orthographic processing studies in view of the use of the capital letter. A large body of research (e.g. Coltheart, Rastle, Perry, Langdon \& Ziegler, 2001; Davis, 2010; Grainger, Rey \& Dufau, 2008) has suggested that words "are recognized exclusively on the basis of case-invariant abstract letter identities" (Martin \& Davis, 2019: 748), meaning that uppercase or lowercase does not affect how fast 
words are recognized or processed. Nonetheless, there are studies that point to the relevance of the initial capital letter in word processing. For example, Rayner and Schotter (2014: 1625) found that "in English, a word that has the first letter capitalized draws more attention than when the word is not capitalized, leading to larger preview benefits". Similarly, Peressotti, Cubelli, and Job (2003: 106) found that proper nouns with the initial capital letter are, in Italian, "recognized consistently faster than common nouns written in the same format", concluding that "the capitalized first letter is a crucial orthographic cue able to speed up recognition of written words" (Peressotti et al., 2003: 111).

Finally, at the end of literature review, it needs to be noted that we could not refer to any scientific research regarding the topic of this paper as no such research exists - in either Croatian or English.

\section{STUDY I}

\subsection{Research aim and question}

The aim of the first study was to find out what the practice is regarding writing select words with an initial lowercase letter at the beginning of a sentence, both in Croatian and English. The first study is to answer the following question: How frequently do select words with an initial lowercase letter appear at the beginning of a sentence in the original form and with an uppercase letter in the Croatian and the English corpus?

\subsection{Method}

\subsubsection{Corpora}

To find an answer to the research question, we analyzed the Croatian and the English corpus. The Croatian corpus, $\mathrm{hrWaC} 2.2$, is a corpus of texts collected from the internet in 2013, and it contains more than 1.3 billion tokens. The English corpus, English Web 2015 (enTenTen15), is a corpus of texts crawled from the internet in 2015, and it contains more than 18.3 billion tokens. SketchEngine ${ }^{8}$ was used to access the corpora.

\subsubsection{Procedure}

The corpora were accessed and analyzed in February 2020. The target items searched in the corpus were $p H$, iPhone, eBay, adidas, will.i.am, and danah boyd. $\mathrm{pH}$ was selected as a representative abbreviation familiar to many people with a high school degree, iPhone as a well-known brand, eBay as a familiar company that uses intercaps (although, interestingly, their logo is styled

\footnotetext{
${ }_{8}^{8}$ https://www.sketchengine.eu/
} 
entirely in lowercase letters), adidas as a famous company that styles its name entirely in lowercase, will.i.am as a stage name of a popular American musician who writes it in lowercase (and with periods in between), and danah boyd as a first and last name of an American researcher who writes it in lowercase.

\subsection{Results and discussion}

As can be seen in Table 1, the words iPhone, eBay, adidas, and will.i.am do appear at the beginning of a sentence with an initial lowercase letter in the Croatian corpus, while $\mathrm{pH}$ and danah boyd do not (note that the latter name, as we expected, does not appear in the Croatian corpus at all). We can notice that iPhone, eBay, and will.i.am are written predominantly with an initial lowercase letter when located elsewhere in a sentence (Total occurrences initial lowercase), but that they are more often capitalized than not when found at the beginning of a sentence. Interestingly, adidas is most often capitalized regardless of the position in a sentence. We would imagine that adidas prefers to be styled in lowercase letters, judging, for example, from their promotional article published on Telegram ("adidas vas poziva...", 2019) in which adidas is placed at the beginning of two paragraphs, for example: "adidas trgovina u Ilici 21 jedinstven je prostor..." ('adidas store in Ilica 21 is a unique space..."). However, it appears that the fact that this brand name is lowercased is not sufficiently salient.

Table 1. Occurrences in the Croatian corpus

\begin{tabular}{|l|c|c|l|c|c|}
\hline $\begin{array}{c}\text { Proper noun or } \\
\text { abbreviation } \\
\text { (lemma) }\end{array}$ & $\begin{array}{c}\text { Total } \\
\text { occurrences } \\
- \text { initial } \\
\text { lowercase }\end{array}$ & $\begin{array}{c}\text { Beginning } \\
\text { of sentence } \\
- \text { initial } \\
\text { lowercase }\end{array}$ & $\begin{array}{c}\text { Proper } \\
\text { noun or } \\
\text { abbreviation } \\
\text { (lemma) }\end{array}$ & $\begin{array}{c}\text { Total } \\
\text { occurrences } \\
- \text { initial } \\
\text { uppercase }\end{array}$ & $\begin{array}{c}\text { Beginning } \\
\text { of sentence } \\
\text { - initial } \\
\text { uppercase }\end{array}$ \\
\hline $\mathrm{pH}^{*}$ & 338 & 0 & - & - & - \\
\hline iPhone & 26,854 & 342 & $\begin{array}{l}\text { Iphone } \\
\text { IPhone }\end{array}$ & $\begin{array}{c}914 \\
148\end{array}$ & $\begin{array}{c}159 \\
38\end{array}$ \\
\hline eBay & 2,992 & 30 & $\begin{array}{l}\text { Ebay } \\
\text { EBay }\end{array}$ & 425 & 72 \\
\hline adidas & 850 & 64 & Adidas & 2,550 & 25 \\
\hline will.i.am & 138 & 2 & Will.i.am & 76 & 334 \\
\hline danah boyd & 0 & 0 & $\begin{array}{l}\text { Danah Boyd } \\
\text { Danah boyd }\end{array}$ & 4 & 1 \\
\hline
\end{tabular}

${ }^{*}$ The abbreviation $\mathrm{pH}$ in the form with an initial uppercase letter $(\mathrm{PH})$ was not analyzed in the corpus because of ambiguity; for example, PH in Croatian can stand for "Prvenstvo Hrvatske" ('Championship of Croatia'), and many results refer in fact to this and not to 'power of hydrogen'.

An interesting observation is that iPhone is the only target item that has more occurrences with an initial lowercase at the beginning of a sentence than with an initial uppercase. 
As evident from Table 2, all of the words do appear with an initial lowercase letter at the beginning of a sentence in the English corpus. For the words iPhone and eBay, the initial lowercase letter at the beginning of a sentence is more frequent than other options (initial uppercase letter or two capital letters). The names adidas, will.i.am, and danah boyd are predominantly capitalized at the beginning of a sentence. It is interesting to note that the form Danah boyd did not appear even once. However, here it needs to be noted that this name could appear just as a first name or a last name. For example, McCulloch (2019) uses only the last name at the beginning of a sentence: "...the sites in her book stretch from MySpace to Instagram. boyd links the impetus for younger people to socialize online with restrictions..." (p. 159-160). Individual components were not searched in the corpus because of the ambiguity of who they refer to.

Table 2. Occurrences in the English corpus

\begin{tabular}{|l|c|c|l|c|c|}
\hline $\begin{array}{c}\text { Proper noun or } \\
\text { abbreviation } \\
\text { (lemma) }\end{array}$ & $\begin{array}{c}\text { Total } \\
\text { occurrences } \\
\text { - initial } \\
\text { lowercase }\end{array}$ & $\begin{array}{c}\text { Beginning } \\
\text { of sentence } \\
- \text { initial } \\
\text { lowercase }\end{array}$ & $\begin{array}{c}\text { Proper } \\
\text { noun or } \\
\text { abbreviation } \\
\text { (lemma) }\end{array}$ & $\begin{array}{c}\text { Total } \\
\text { occurrences } \\
- \text { initial } \\
\text { uppercase }\end{array}$ & $\begin{array}{c}\text { Beginning } \\
\text { of sentence } \\
\text { - initial } \\
\text { uppercase }\end{array}$ \\
\hline $\mathrm{pH}^{*}$ & 126,032 & 685 & - & - & - \\
\hline iPhone & 521,833 & 5,297 & $\begin{array}{l}\text { Iphone } \\
\text { IPhone }\end{array}$ & $\begin{array}{c}16,790 \\
6,166\end{array}$ & $\begin{array}{c}2,523 \\
1,189\end{array}$ \\
\hline eBay & 95,407 & 1,508 & $\begin{array}{l}\text { Ebay } \\
\text { EBay }\end{array}$ & $\begin{array}{c}14,582 \\
3,295\end{array}$ & 1,324 \\
\hline adidas & 409 & 85 & Adidas & 30,030 & 4,63 \\
\hline will.i.am & 961 & 53 & Will.i.am & 539 & 82 \\
\hline danah boyd & 269 & 9 & $\begin{array}{l}\text { Danah Boyd } \\
\text { Danah boyd }\end{array}$ & 357 & 0 \\
\hline
\end{tabular}

*See note in Table 1.

Thus, corpus analysis has shown that in Croatian proper nouns with an initial lowercase letter are generally written more frequently in uppercase than lowercase when placed at the beginning of a sentence, except for iPhone; in the English corpus, iPhone and eBay are predominantly written with an initial lowercase letter at the beginning of a sentence. The ubiquity of the brand iPhone is evident in the total number of occurrences in both languages and may explain its special treatment, whereby speakers seem to grant $i$ Phone a special status by letting the name keep its orthographic form regardless of the position in a sentence. 


\section{STUDY II}

\subsection{Research aim and questions}

The aim of the second study was to gain an insight into what bilingual college students find acceptable regarding writing select words with an initial lowercase letter at the beginning of a sentence, in Croatian and English. The second study is to answer the following questions:

1) Which spelling of select words with an initial lowercase letter do the participants find more acceptable at the beginning of a sentence?

2) What reasons lie behind the participants' acceptability judgments?

\subsection{Method}

\subsubsection{Instrument and procedure}

To find answers to the research questions, we used a survey with acceptability judgment tasks. The survey consisted of two general questions (age, gender) and six items (judgment acceptability tasks) related to the use of a lowercase or uppercase letter at the beginning of a sentence. The target items were the same as in the corpus analysis: $p H$, iPhone, eBay, adidas, will.i.am, and danah boyd. There was an optional comment section at the end of the survey. The six items required participants to mark the passages in which they find the spelling of a particular word acceptable; the instructions for each item included a note that the company/person styles/writes the name with an initial lowercase letter (or all lowercase letters). The participants could check more than one passage as acceptable.

A special note was provided explaining that 'acceptable' means that the participant would write the word in a particular way himself/herself or would not mind seeing it written in a particular way in an article on a news site. This note set the frame for the level of formality, which was also helped by the phrasing of individual passages. Hence, the participants were able to gather that the genre of writing is neither an informal one like a text message nor a very formal one like an essay.

Each passage consisted of an introductory sentence that did not contain the target item and another sentence in which the target item was placed at the beginning. In the first row the target item was written with an initial lowercase letter and then with an uppercase letter or letters in the second and third row, as can be seen in the following example:

The app is available on Android phones. iPhone users will have to wait for the app for another week.

The app is available on Android phones. Iphone users will have to wait for the app for another week.

The app is available on Android phones. IPhone users will have to wait for the app for another week. 
The survey was created in English and translated into Croatian, and the English survey was distributed to one group of participants and the Croatian to another in March 2020.

\subsubsection{Participants}

There were 60 participants, all students of International Business at an American college in Croatia. Their average age was 21, and they were bilingual speakers with L1 Croatian and L2 English. They were divided into two groups of 30 participants, randomly; Group 1 took the Croatian survey and Group 2 took the English survey. In Group 1, there were 16 male and 14 female participants, and in Group 2 there were 18 male and 12 female participants.

One of the reasons we chose to survey college students on this matter is that we were interested in the attitudes of digital natives - young people born into the world where written communication is primarily digital and, at their age, mostly informal (and hence with loose punctuation and capitalization rules).

\subsection{Results and discussion}

We shall take a look at the participants' responses to each of the six target items in the Croatian and the English survey. Note that the participants were allowed to check more than one option as acceptable, which is why the number of responses does not add up to the number of participants.

Figure 1 shows the participants' responses regarding the writing of $p H$ at the beginning of a sentence.

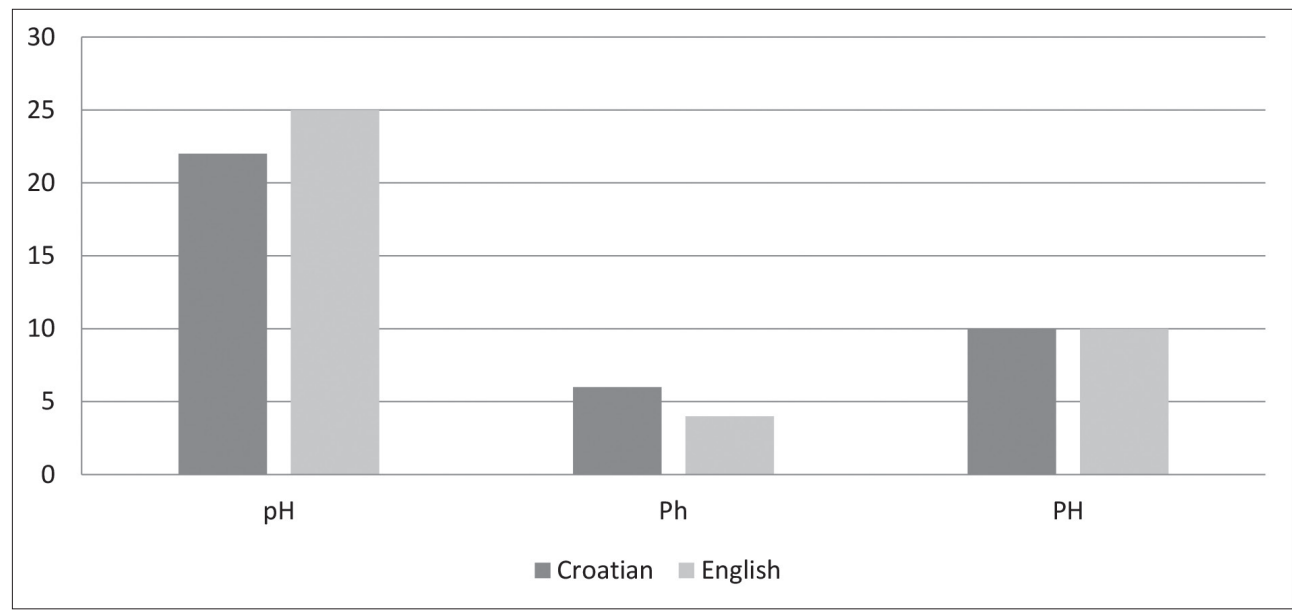

Figure 1. Number of participants who indicated that a particular way of writing $\mathrm{pH}$ at the beginning of a sentence is acceptable 
It is clear that the most acceptable form is with the initial lowercase letter, with slightly more participants in the English survey choosing this option.

Similar results were obtained for iPhone, as evident in Figure 2.

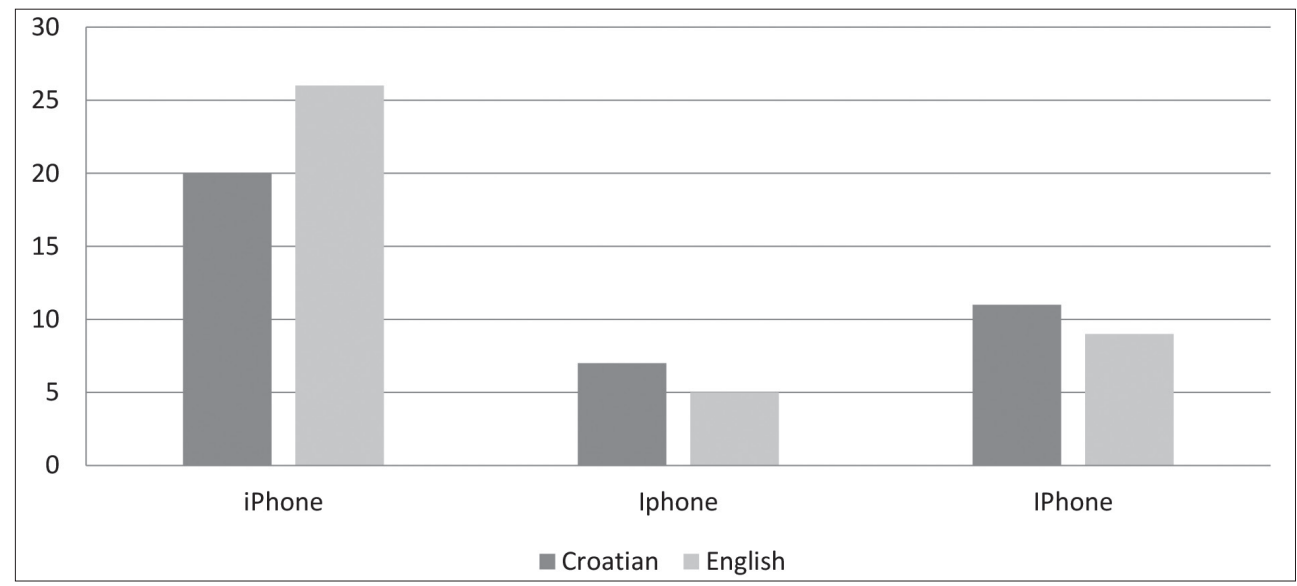

Figure 2. Number of participants who indicated that a particular way of writing iPhone at the beginning of a sentence is acceptable

Looking at the results for eBay (Figure 3), we notice slightly more participants indicating that it would be acceptable to capitalize the first letter but lowercase the second (Ebay) at the beginning of a sentence when compared to $\mathrm{pH}$ or iPhone. In addition, a pattern seems to emerge when we compare the two languages in these three intercapped words: fewer participants in the Croatian survey seem to find it acceptable to begin a sentence with a lowercase letter when compared with the responses in the English survey. The difference is slight with $p H$ but increases with iPhone and eBay.

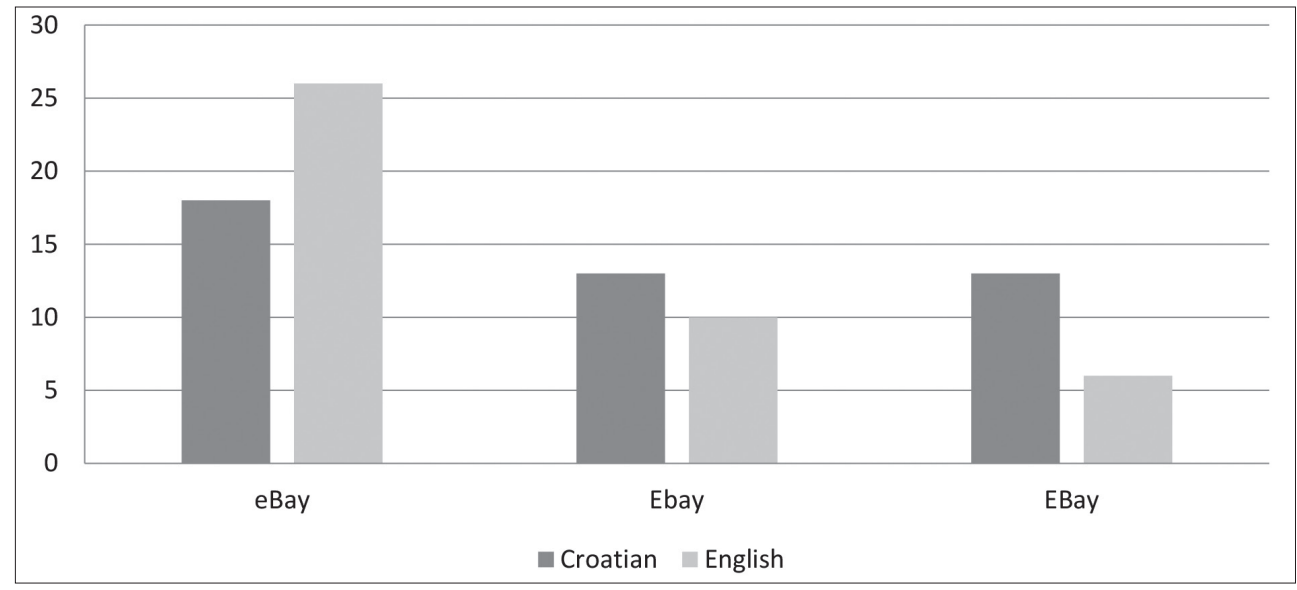

Figure 3. Number of participants who indicated that a particular way of writing eBay at the beginning of a sentence is acceptable 
In view of writing adidas, there were two options, and for all the participants, in both groups, the most acceptable way was to capitalize the name of this sports apparel company at the beginning of a sentence (Figure 4). The lowercased name was an acceptable option only for several participants.

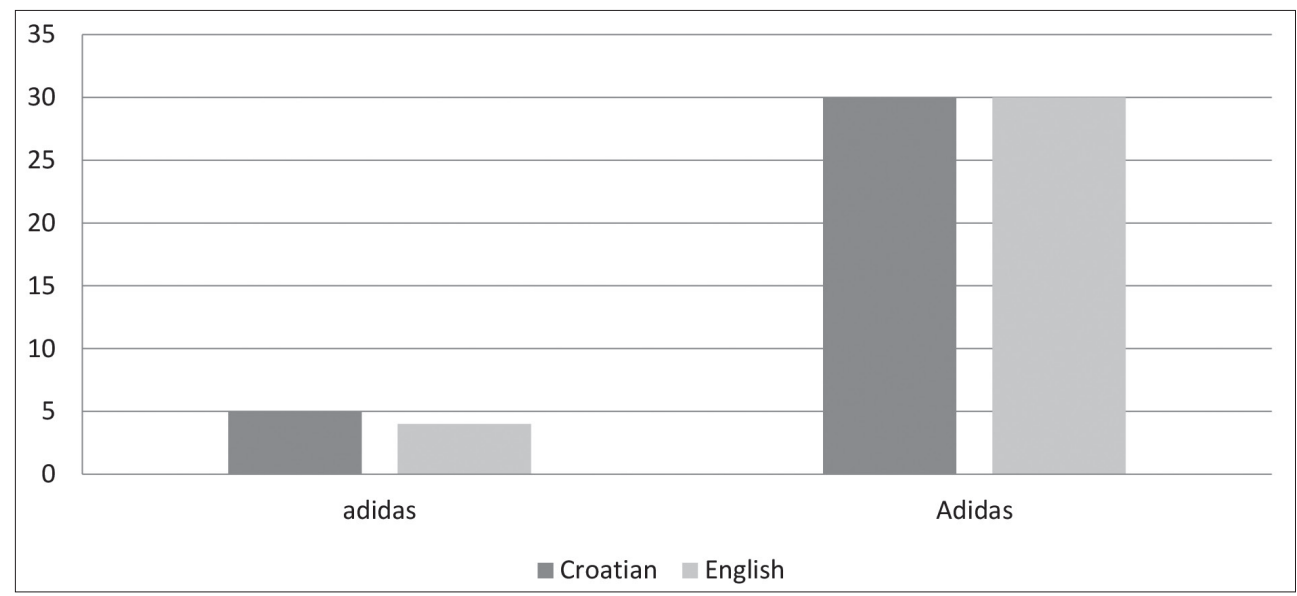

Figure 4. Number of participants who indicated that a particular way of writing adidas at the beginning of a sentence is acceptable

When it comes to writing the lowercased personal name will.i.am at the beginning of a sentence, this appears to be acceptable for nearly half of the participants in both languages, as evident in Figure 5. Interestingly, for ten participants in the English sample and six in the Croatian sample, capitalizing this personal name at the beginning of a sentence would not be acceptable at all.

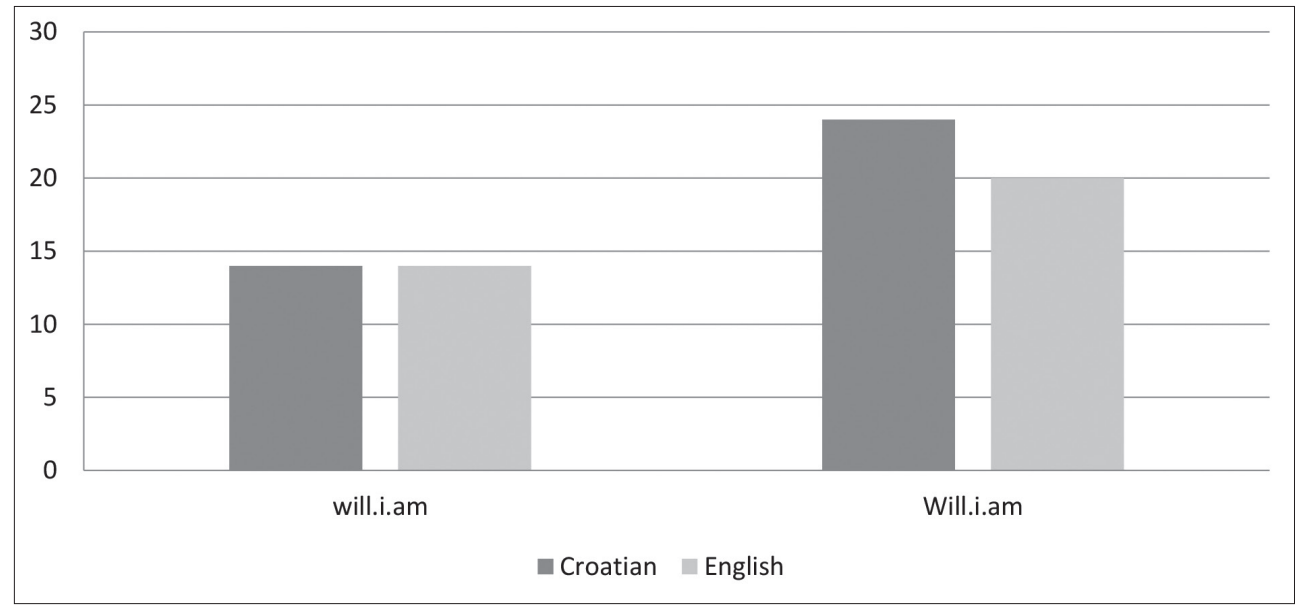

Figure 5. Number of participants who indicated that a particular way of writing will.i.am at the beginning of a sentence is acceptable 
Although danah boyd is a personal name, as is will.i.am, the results show that writing the former name in lowercase letters at the beginning of a sentence is acceptable only to a small number of participants (Figure 6). For most participants, the most acceptable option would be to capitalize both the first and the last name. Interestingly, slightly more than a third of participants find it acceptable to capitalize just the first name and leave the last name in lowercase letters, thus partly respecting the author's preference and the capitalization rule at the same time.

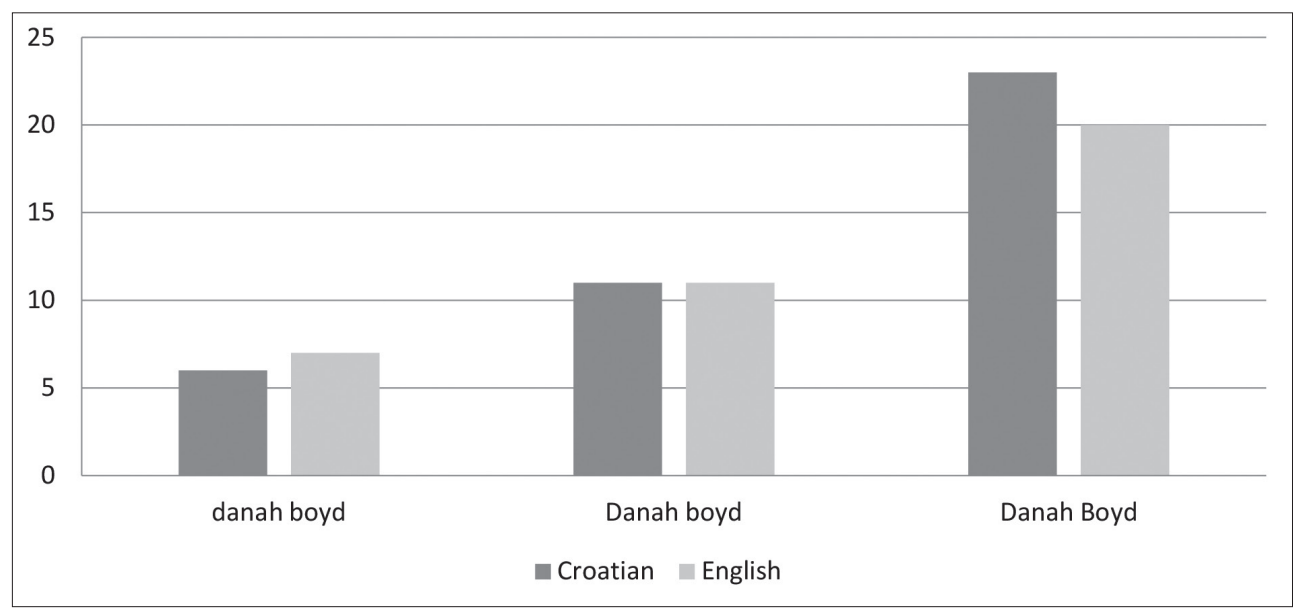

Figure 6. Number of participants who indicated that a particular way of writing danah boyd at the beginning of a sentence is acceptable

Finally, considering that the responses in the Croatian and the English survey were similar to a large degree, we shall take a look at the combined results for the six target items in Figure 7. 


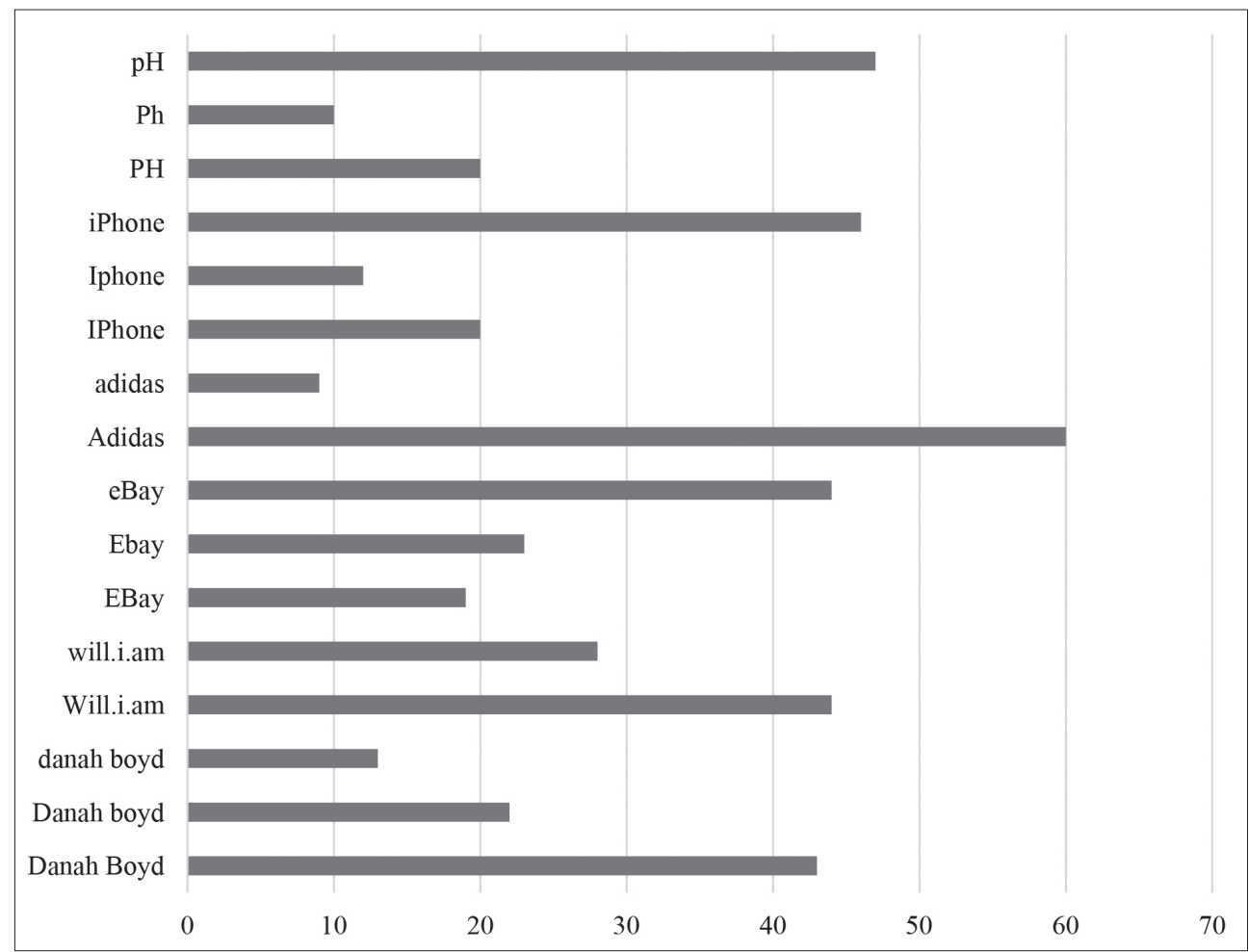

Figure 7. Combined responses (Croatian and English) on all items

We see that all of the participants find capitalizing adidas at the beginning of a sentence acceptable. More than $2 / 3$ of participants find capitalizing personal names will.i.am and danah boyd at the beginning of a sentence acceptable. Regarding the intercapped words ( $p H$, iPhone, eBay), writing them with the initial lowercase letter at the beginning of a sentence is acceptable to around $3 / 4$ of participants.

Thus, it appears that the participants, 21-year-old college students, are more open to the idea of starting a sentence with a lowercase letter in case of intercapped words ( $p H$, iPhone, eBay) as opposed to all-lowercase words (adidas, will.i.am, danah boyd). Comments by several participants may provide us with some reasons for this discrepancy:

(1) "I realized that if it is a word like eBay or iPhone, where there is a capital letter in the middle of the word, I find it acceptable for a sentence to start with a lowercase letter. However, if the whole word is lowercase it just seems wrong for the sentence to start with a lowercase letter."

(2) "For some reason, some things are naturally spelled with lowercase, such as iPhone, but I feel that whenever it is a person, it is weird for it to be started by lowercase, such as the last one - Danah Boyd." 
(3) "In my case, I see the way I choose when it's OK to have a lowercase letter at the beginning of a sentence depends on how the word looks, for example, if it is a name of a person I find it unusual to see it written in lowercase letter, but then again, if someone chose it like that, I respect that. On the other hand, the names of companies and products and abbreviations that have been spelled like that for a long time look good to me, regardless of the fact that the letter at the beginning of the sentence is in lowercase." (Translated from Croatian.)

(4) "iPhone like eBay just seems more natural to see it written as a 'brand' than capitalizing it on your own, it just looks more normal." (Translated from Croatian.)

(5) "Adidas is the name of the brand and I honestly didn't think of the company spelling it in lowercase letters but it looks 'cooler' in lowercase letters on apparel but in the text I would capitalize it." (Translated from Croatian.)

The reason, thus, may be that the intercapped words do have a capital letter in them, which might make such words more visually acceptable at the beginning of a sentence in contrast with words in all lowercase letters. Another reason may be that brands are simply perceived differently than other proper nouns, especially names.

In view of personal names, there were two insightful comments that point to the issue of respecting the name-bearer's preference.

(6) "For the names of individuals, for example, I made decisions using the idea that, if this is someone's choice to be referred to with in such a manner, then we should respect their decision, especially in cases where there is the artist's freedom to choose their artistic names."

(7) "I really think this is a thing of huge importance to any language. Should we respect the freedom of scientists and artist, in terms of calling themselves creative names more than we respect the grammar of a language? Does respecting one means rejecting the other?"

Indeed, as Einsohn (2006) wisely noted, while most authors do not care much for capitalization, there are those for whom capitalization "is not merely a matter of typography but an issue of according or denying status to a term" (p. 152). Similarly, a person may feel quite strongly about the initial lowercase letter in their name. For example, danah boyd has a page dedicated to explaining her choice of lowercase letters (boyd, n.d.), and brian $\mathrm{d}$ foy, a publisher and editor, has a style guide page regarding how his name should be dealt with in writing (foy, n.d.).

In this context it is interesting to note that twice as many participants find it acceptable to write will.i.am in contrast to danah boyd in lowercase letters at the beginning of a sentence. This may be because the participants are more familiar with the identity of will.i.am than danah boyd, or the fact that the first name consists of one word and the second of two words. It could also be that will.i.am is already "extravagant" enough with the periods within the 
name, while danah boyd seems like a more common name and should thus follow the "common" rules.

Another thought-provoking point is that a third of participants find it acceptable to capitalize the first name but leave the last name in lowercase letters for danah boyd, hence Danah boyd. This is perhaps an attempt to reconcile two rules - the one that allows for personal names to be written in lowercase letters (e.g. Ritter, 2003; The Chicago Manual of Style, 2017; Trask, 1997), respecting thus the person's preference, and the fundamental rule of capitalizing the first letter in a sentence (note that this way of writing the researcher's name did not show up in corpus analysis).

Finally, one participant made what at first appears to be a valid point in favor of capitalizing the first letter at the beginning of a sentence:

(8) "But, for example, the word house is also written in lowercase letters, but when it is at the beginning of a sentence it is written House because those are the grammar rules that a sentence starts with a capital letter, so I believe that in this case it should be the same." (Translated from Croatian.)

However, we should not forget that house is not like the other words in the study as it is not a proper noun. We have established that proper nouns with an initial lowercase letter already have a special treatment within the sentence, unlike the word house.

At this point we would like to return to an indication of a pattern that emerged in the survey results based on the difference in languages. More participants in the English survey in contrast to those in the Croatian survey were open to the idea of starting a sentence with a lowercase letter when it comes to the words $p H$, iPhone, eBay, and danah boyd. Sometimes this difference is slight but other times it is quite noticeable. There is a possible explanation for this. The participants' L1 is Croatian, which could mean that they are more familiar with the Croatian capitalization rules and thus more certain that a sentence needs to start with a capital letter without exception. However, the survey did not test the participants' knowledge of rules; rather, it examined their attitudes in terms of what they find acceptable, which was clearly explained in the survey. Nonetheless, even though they were not tested on rules, the participants, being perhaps more familiar with the rules in Croatian, might have perceived Croatian as being more regulated in this regard than English, finding thus the lowercase letter at the beginning of a sentence acceptable in fewer cases in Croatian than in English.

\section{GENERAL DISCUSSION}

Literature review has shown that rules regarding the initial lowercase letter of proper nouns and abbreviations and placing such words at the beginning of a sentence differ in handbooks and style guides, in both Croatian and 
English. Regardless of the language, most of the analyzed handbooks do not address the matter at all, and those few that do, seem to be inconsistent when it comes to the rule governing the initial letter of the word at the beginning of a sentence. Thus, Jozić (2013) explicitly allows for $e$-words to start a sentence, but does not mention $i$-words, to which they do grant special status as proper nouns written with a lowercase letter. APA Publication Manual (American Psychological Association, 2020) does not provide an explanation why van de is alright at the beginning of a sentence, but not $e$ Bay or an abbreviation with an initial lowercase letter. For Walsh (2004), eBay is acceptable, but not $k$. $d$. lang, and neither at the beginning of a sentence. The Chicago Manual of Style (2017) is the only one that offers an explanation of its different treatment of initial lowercase and all lowercase proper nouns - the capital letter in intercapped words indicates it is a proper noun. Hence, the latter type can be written thus at the beginning of a sentence. And while CMOS states that the spelling of personal names should be respected, it warns that most editors will capitalize the personal name at the beginning of a sentence or reword the sentence. Seeing that editors follow manuals and guides, it is unclear why CMOS engages in circular reasoning ("you should not do it because it is not done") instead of setting the rule clearly.

In response to the research question from Study I, "How frequently do select words with an initial lowercase letter appear at the beginning of a sentence in the original form and with an uppercase letter in the Croatian and the English corpus?", we found that intercapped words with an initial lowercase letter (iPhone in the Croatian corpus and iPhone and eBay in the English corpus) appear more frequently in that form at the beginning of a sentence in comparison to lowercased personal names, which tend to be written with an uppercase letter.

In response to the research questions from Study II, "Which spelling of select words with an initial lowercase letter do the participants find more acceptable when the word is at the beginning of a sentence?" and "What reasons lie behind the participants' acceptability judgments?", we found that intercapped words are treated differently from lowercased words in that more participants find it acceptable to use the initial lowercase letter at the beginning of a sentence in case of the former. Some participants explained that intercapped words, brand names, simply "seem more natural" and that they have become accustomed to them being spelled with an initial lowercase letter.

We recognize several limitations of our research. In view of the first study, the Croatian corpus was built on web texts from 2013 and the English corpus on web texts from 2015, meaning that they do not perhaps accurately reflect contemporary usage, which might show a different trend. In addition, only six items were included in the analysis, as was the case in the second study. 
Furthermore, pertaining to the second study, the sample size is modest and includes only students, and other levels of formality were not explored, such as whether the practice of not capitalizing the first letter at the beginning of a sentence is present or would be acceptable in, for example, very formal texts such as journal articles.

Despite the limitations, we believe that our findings are relevant and that they have implications for orthography development. Hence, based on literature review, corpus analysis, and survey results, we propose the following:

1) The Croatian orthography handbook (Jozić, 2013), which already allows for $e$-words with an initial lowercase letter to be placed at the beginning of a sentence, should expand this rule to include other intercapped proper nouns and abbreviations, such as $\mathrm{pH}, \mathrm{eBay}$, iPhone etc. (There are Croatian companies with intercapped names as well, such as iService and iKlinika.)

2) The rule regarding not capitalizing intercapped words at the beginning of a sentence should be recognized in English as well, as is already explicitly stated in The Chicago Manual of Style (2017).

Regarding words written in all lowercase letters, whether company or personal names, we cannot make a proposal based on evidence gathered in this study. However, we will elaborate on our stance on the matter. We believe that because these words are already given special treatment within a sentence (e.g. Ritter, 2003; The Chicago Manual of Style, 2017; Trask, 1997), there is no valid reason for their status to change depending on their position in a sentence. If an exception has been made for words like iPhone and eBay, then we must understand that a precedent has been set that a sentence need not begin with a capital letter. This, in turn, opens the door for other words with an initial lowercase letter to claim their position at the beginning of a sentence.

Furthermore, if lowercased names are to be respected within a sentence, as is called for in several orthography handbooks and style guides, but capitalized at the beginning of a sentence, as advocated in most handbooks and guides, and suggested by the results of our research, what would happen with a name like danah boyd - would it be written Danah boyd or Danah Boyd? What rule would justify capitalizing boyd in that case, since it is not the first word in a sentence? Next, based on what can we grant iPhone the right to keep its lowercase $i$ at the beginning of a sentence but take that right away from bell hooks? This surely cannot be based on the subjective impression that one looks better than the other. We must also take into account that as our online identities begin to gradually permeate our "real" lives, identities and usernames from social media platforms will enter other discourses and genres. Seeing that usernames are often and purposefully written in lowercase, such as ann belle or side_kick5, capitalization rules will need to accommodate these new types of proper nouns. 
Finally, our stance not to capitalize proper nouns in all lowercase letters at the beginning of a sentence might be countered with questions about the readability of sentences that start with a lowercase letter. However, if the findings from orthographic processing studies referred to in literature review are not taken into account for the treatment of intercapped or lowercased proper nouns within a sentence, they can hardly be used as an argument for capitalizing such words at the beginning of a sentence; after all, the previously mentioned orthographic processing studies were done at word, not sentence level.

\section{CONCLUSION}

Our research, based on literature review and two studies, has found that rules and practices regarding starting a sentence with a proper noun or an abbreviation with an initial lowercase letter vary in Croatian and English.

In terms of rules, they are anything but systematic or comprehensive. In Croatian, only $e$-words are allowed to keep the initial lowercase letter at the beginning of a sentence. In English, the rules differ from one style guide to the other, with most guides not addressing the issue at all when it comes to starting a sentence. APA Publication Manual and CMOS are the only ones that do explicitly allow the initial lowercase letter at the beginning of a sentence in certain cases.

Corpus analysis has shown that practices also vary, but the emerging pattern is that intercapped words such as iPhone or eBay are found more frequently with an initial lowercase letter at the beginning of a sentence than their capitalized counterparts. The opposite is true for lowercased proper nouns, personal names danah boyd and will.i.am, which are found capitalized at the beginning of a sentence more frequently than not.

The discrepancy between intercapped words and lowercased personal names has surfaced in the survey as well. The participants find it more acceptable to leave intercapped words (brand names) lowercased, while they prefer to capitalize otherwise lowercased proper nouns (personal names) at the beginning of a sentence.

The limitations of the study point to the need for further research that would be based on more recent corpora, more target items, different types of texts, and participants of different ages and occupations. Further research should also explore more thoroughly the reasons behind the participants' choices. Finally, it might be a good idea to study intercapped words separately from other lowercased words, as well as to research proper nouns separately from abbreviations.

To conclude, writing in the digital age may require reimagining some centuries old punctuation and capitalization rules. Writing is no longer an exclusive and highly formal endeavor, but an integral part of our daily 
communication - through messages, posts, comments we have come to write more and more often. This communication is understandably informal, but it is certain that some of the (orthographic) practices we engage in are bound to affect formal writing as well.

Although breaking one of the fundamental rules of writing, starting a sentence with a capital letter, might be perceived as a sign of falling standards, we should not forget that language change is inevitable - it has not spared any aspect of language thus far, so we may expect a more lenient approach to capitalization as well. The capital letter will not go away any time soon, but now and then a word with an initial lowercase letter will find itself heading a sentence.

\section{REFERENCES}

American Psychological Association (2020) Publication Manual of the American Psychological Association (7 $7^{\text {th }}$ edition). [Electronic edition.] Washington: American Psychological Association.

Anić, V. \& Silić, J. (2001) Pravopis hrvatskoga jezika. Zagreb: Novi Liber i Školska knjiga.

Babić, S. \& Moguš, M. (2011) Hrvatski pravopis. Zagreb: Školska knjiga.

Badurina, L., Marković, I. \& Mićanović, K. (2008) Hrvatski pravopis. Zagreb: Matica hrvatska.

Baranick, J. (2014) Kiss My Asterisk. [Electronic edition.] New York: Skyhorse Publishing.

Burchfield, R. W. (1998) The New Fowler's Modern English Usage (revised ${ }^{\text {rd }}$ edition). Oxford: Oxford University Press.

Coltheart, M., Rastle, K., Perry, C., Langdon, R. \& Ziegler, J. (2001) DRC: A dual route cascaded model of visual word recognition and reading aloud. Psychological Review 108 (1), $204-256$. doi:10.1037/0033-295x.108.1.204

Crystal, D. (2004) The Language Revolution. [Electronic edition.] Cambridge: Polity Press.

Crystal, D. (2005) The Cambridge Encyclopedia of the English Language (2 ${ }^{\text {nd }}$ edition). Cambridge: Cambridge University Press.

Crystal, D. (2006a) The Fight for English. How Language Pundits Ate, Shot, and Left. Oxford: Oxford University Press.

Crystal, D. (2006b) Language and the Internet (2 ${ }^{\text {nd }}$ edition). Cambridge: Cambridge University Press.

Crystal, D. (2012) Spell It Out: The Curious, Enthralling, and Extraordinary Story of English Spelling. London: Profile Books.

Crystal, D. (2015) Making a Point: The Persnickety Story of English Punctuation. [Electronic edition.] London: Profile Books.

Davis, C. J. (2010) The spatial coding model of visual word identification. Psychological Review 117 (3), 713-758. doi:10.1037/a0019738

Einsohn, A. (2006) The Copyeditor's Handbook ( $2^{\text {nd }}$ edition). Berkeley: University of California Press.

Grainger, J., Rey, A. \& Dufau, S. (2008) Letter perception: From pixels to pandemonium. Trends in Cognitive Sciences 12, 381-387. doi:10.1016/j.tics.2008.06.006

Jozić, Ž. (Ed.) (2013) Hrvatski pravopis. Zagreb: Institut za hrvatski jezik i jezikoslovlje.

Lovinger, P. W. (2002) The Penguin Dictionary of American Usage and Style. Hardmondsworth: Penguin Reference.

Manser, M. \& Curtis, S. (2002) Penguin Writer's Manual. London: Penguin Books.

Martin, N. \& Davis, J. C. (2019) Evidence from masked-priming that initial identification of brand names is via abstract letter identities. British Journal of Psychology 110, 745-768. doi:10.1111/ bjop. 12362

McCulloch, G. (2019) Because Internet. Understanding the New Rules of Language. [Electronic edition.] New York: Riverhead Books. 
Merriam-Webster's Guide to Punctuation and Style (2 $2^{\text {nd }}$ edition) (2001) Springfield: Merriam-Webster.

Patekar, J. (2016). Razlike u uporabi pravopisnih znakova u hrvatskome i engleskome jeziku. Rasprave Instituta za hrvatski jezik i jezikoslovlje 42 (1), 147-166.

Peressotti, F., Cubelli, R. \& Job, R. (2003) On recognizing proper names: the orthographic cue hypothesis. Cognitive Psychology 47, 87-116. doi:10.1016/S0010-0285(03)00004-5

Peters, P. (2004) The Cambridge Guide to English Usage. Cambridge: Cambridge University Press.

Rayner, K. \& Schotter, E. R. (2014) Semantic preview benefit in reading English: The effect of initial letter capitalization. Journal of Experimental Psychology: Human Perception and Performance 40 (4), 1617-1628. https://doi.org/10.1037/a0036763

Ritter, R. M. (Ed.) (2003) The Oxford Style Manual. Oxford: Oxford University Press.

Seely, J. (2009) Oxford A-Z of Grammar \& Punctuation (2 ${ }^{\text {nd }}$ edition). Oxford: Oxford University Press.

Straus, J., Kaufman, L. \& Stern, T. (2014) The Blue Book of Grammar and Punctuation. [Electronic edition.] San Francisco: Jossey-Bass.

The Chicago Manual of Style (17 th edition) (2017) Chicago: The University of Chicago Press.

Trask, R. L. (1997) The Penguin Guide to Punctuation. Penguin Books. London.

Trask, R. L. (2001) Mind the Gaffe. London: Penguin Books.

Truss, L. (2003) Eats, Shoots \& Leaves. New York: Gotham Books.

Walsh, B. (2004) The Elephants of Style. New York: McGraw-Hill.

Woods, G. (2006) Webster's New World Punctuation: Simplified and Applied. Hoboken: Wiley Publishing.

\section{Web sources:}

adidas vas poziva da pomaknete granice kreativnosti i intervenirate u Ilici 21 (2019) Telegram. https://www.telegram.hr/promo/adidas-vas-poziva-da-pomaknete-granice-kreativnosti-i-intervenirate-u-ilici-21/ (March 24, 2020)

boyd, d. (n. d.) what's in a name? danah.org https://www.danah.org/name.html (March 24, 2020)

foy, b. d. (n. d.) Style Guide. brian d foy. http://www252.pair.com/comdog/style.html (March 24, 2020)

\section{REČENICA NE MORA ZAPOČETI VELIKIM SLOVOM}

U ovome se radu istražuje pitanje započinjanja rečenice osobnom imenicom ili pokratom čije se prvo slovo piše malim slovom (npr. iPhone, danah boyd, $p H$ ). Tradicionalno se izbjegavalo pisanje takvih riječi na početku rečenice, no time se ograničavaju sintaksa i stil. Cilj je stoga ovoga rada istražiti normu i uzus u pogledu pisanja osobnih imenica i pokrata malim početnim slovom te započinjanja rečenice takvim riječima u hrvatskome i engleskome jeziku. Prvo su pregledana pravila i smjernice u pravopisnim i jezičnim priručnicima, potom su analizirani korpusi u obama jezicima kako bi se stekao uvid u uporabu maloga početnoga slova, a na kraju je provedeno istraživanje među 60 dvojezičnih studenata kako bi se ispitalo što oni smatraju prihvatljivim u tome pogledu. Rezultati upućuju na to da rečenica može započeti malim slovom te da prihvatljivost te pojave ovisi o nekoliko čimbenika.

Ključne riječi: veliko slovo, malo slovo, početno slovo, pravopis, osobne imenice, brend.

This work is licensed under a Creative Commons Attribution 4.0 International License.

Ovaj rad dostupan je za upotrebu pod licencom Creative Commons Imenovanje 4.0 međunarodna. 